\title{
ASPECT OF JUSTICE ON PROGRESSIVE TARIFF STIPULATION POLICY ON MOTORIZED VEHICLES TAX IN PAPUA PROVINCE
}

\author{
Hotlan Samosir \\ Faculty of Law, University of Cendrawasih \\ E-mail: hotlan.samosir06@gmail.com
}

\begin{abstract}
This study aims to analyze the implementation of progressive tariffs on motorized vehicles in Papua Province based on Regional Legislation Number 4 of 2011 concerning Regional Taxes. The problem studied in this paper is how aspects of democracy and justice are applied in regional legislation in Papua Province. The study was conducted by using a normative juridical research method which is focused on studying the application of norms in positive law. The application of progressive tax on four-wheeled motorized vehicles in Papua Province required review as it contradicted aspects of democracy and justice as mandated by Law Number 28 of 2009 concerning regional taxes and Regional Retributions. The enactment of the law gave a mandate to the region to form and issue a regional legislation as a legal basis for local tax collection. Based on the mandate, Regional Legislation Number 4 of 2011 concerning Regional Taxes in Papua Province was formed. Thus, the application of the regional legislation has not fully appropriate yet due to the factual consideration that the limitation on the number of four-wheeled vehicles in Papua Province is not due as its density is still at the normal level.
\end{abstract}

Keywords: progressive tariff policy, motorized vehicle

\section{A. INTRODUCTION}

The administration of government is generally to provide services to the citizens so that every citizen of the community can enjoy welfare. Likewise, the regional government, as an extension of the central government, has a broad authority in the context of regional autonomy for the welfare of the people in the region.

Law Number 23 of 2014 concerning Regional Government states "that the implementation of regional government is directed to accelerate the realization of public welfare through improving services, empowerment, and community participation, as well as increasing regional competitiveness by taking into 
account the principles of democracy, equality, justice and peculiarities of a region in the system of the Unitary State of Republic of Indonesia."

The realization of community welfare as stated above is pursued through various types of government activities such as improving service, empowerment, and community participation, as well as increasing regional competitiveness. In this case the essential principles are the principles of democracy, equity, justice, and peculiarities of a region.

Regarding several types of government activities as mentioned above, one of the forms of community participation is the involvement of the community in carrying out their obligations, namely: obedience in paying taxes. With the enactment of Law Number 28 of 2009 concerning Regional Taxes and Regional Retributions, the Regional Government has an authority to form a regional legislation concerning regional taxes. Regional legislation established in Papua Province is Papua Province's Regional legislation Number 4 of 2011 concerning Regional Taxes.

In Point or Letter a of the considering section, the Regional Legislation emphasizes that regional taxes are important sources of the regional income in order to fund the administration of regional government and development to strengthen its broad, real, and responsible autonomy.

The importance of local taxes as sources of regional income is carried out based on the law concerning regional taxes and regional retributions, which emphasizes that local tax policies and regional retributions are carried out based on democratic principles, equity and justice, community participation, and accountability while considering regional potentials.

Based on these considerations, the actual lawmakers want tax collection from the people to have positive impacts on tax subjects as taxpayers. In accordance with the principle of democracy which was initiated by democratic thinkers, democracy means government that comes from the people, by the people, and for the people.

Based on the description above, the tax collection must still pay attention to the benefits for the people so that the people are the main focus or target of 
tax collection. Democracy requires the implementation of justice in all aspects of governance. Therefore the collection of local taxes is one of the ways to obtain funds to optimize the implementation of regional autonomy. The regional government is part of the Government of the Republic of Indonesia who aspires to carry out the welfare of the people, as stated by Utrecht, so the state of material law has a broader implication including keeping the justice. The role of the state is not only to maintain order by carrying out the law, but also to achieve people's welfare as a form of justice (Utrecht, 1962:2).

\section{B. PROBLEM STATEMENT}

Based on the above descriptions, the problem in this study is formulated as follows: Is the progressive tariff stipulation policy in accordance with the principles of democracy, and justice in Papua Province?

\section{RESEARCH METHODS}

This study was conducted by using normative juridical research method, that is, a research focused on studying the application of norms in positive law (Johny Ibrahim., 2006: 295). This concept views law as identical to written norms that are made and enacted by an authorized institution or official. This conception views law as a normative system that is independent, closed and detached from the real lives of the people (Ronny Hanitijo Soemitro, 1988: 1314).

\section{RESEARCH RESULTS AND DISCUSSION}

\section{Analysis of Progressive Motor Vehicle Tax rates in Regional Legislation Number 4 of 2011 concerning Regional Taxes.}

General provisions of Article 1, Number (6) of Law Number 23 of 2014 concerning Regional Government provides a comprehension that regional autonomy is the right, authority, and obligation of an autonomous regions to regulate and manage themselves. Based on this, the local governments have the 
responsibility to ensure the success of all government operations, including finding sources of Regional Original Income (PAD).

In Regional Legislation Number 4 of 2011 concerning Regional Taxes in the Province of Papua, in Point or Letter a of the considering section, stated that local taxes are important sources of regional income to fund regional governance and development in order to establish broad, real and responsible regional autonomy. The regional tax paid by each taxpayer is collected by the regional government whose allocation is to finance the administration of government including the provision of public facilities.

Paragraph (1) of Article 8 of Regional legislation Number 4 of 2011 concerning regional taxes, states, "The ownership of a second private motorized vehicle and so on is subject to progressive tariffs." Subsequently, in Paragraph (2), the progressive tariffs for 4-wheeled motorized vehicles as referred to in Paragraph (1) are as follows:

a. the second ownership is $2 \%$ (two percent);

b. the third ownership is $2.5 \%$ (two point five percent);

c. the fourth ownership is $3 \%$ (three percent); and

d. the fifth ownership and so on is $3.5 \%$ (three point five percent)."

In general, the idea of the regional government in determining progressive tariffs on Motorized Vehicle Taxes (PKB) is as a policy to impose indirect restrictions on the growth of the number of vehicles. The high growth of motorized vehicles in urban areas can cause traffic congestion problems and air pollution caused by exhaust emissions. Transportation emissions are proved to be the highest contributors to air pollution, which is around $85 \%$ (Ismiyati et. al., 214:243). 
The implementation of the progressive tariff stipulation policy, based on the author's observation, gave no signs that there would be a decline in the number of motorized vehicles in Indonesia. According to data from the Traffic Corps, the number of vehicles operating throughout Indonesia from 2011 to 2013 increased by $12 \%$ (Ismiyati, et al., 214: 243).

Specifically in Papua Province, the growth in the number of motorized vehicles increases every year. It can be seen from the increase in Regional Original Revenue (PAD) sourced from the PKB. For example the tax rate of the PKB in 2014 was Rp155, 908, 149, 639.00 whereas in 2015 it was Rp170, 983, 705, 271.00, increasing by 9.67\% (The Regional Agency of Papua Province, 2015: 19). In terms of regional income growth, this is categorized to be very well because the increase in regional income is associated with the regional development.

Based on Paragraph (5) of Article 8 of Law Number 28 of 2009, the results of the PKB revenues are at least ten percent, including those distributed to districts/cities, allocated for the distribution and/or maintenance of roads and improvement of modes and public transportation. This obligation is called earmarking, which is an obligation of the provincial government to allocate a portion of the regional tax revenue to fund the construction of facilities and infrastructure that can be directly enjoyed by taxpayers and the entire community (Marihot Pahala Siahaan, 2013:179).

The density of motorized vehicles in Papua Province is lower than any other regions in Indonesia. According to data from the Ministry of Public Works and Public Housing (PUPR) the ratio of road length in Papua and West Papua only reached 33.45. This means that every one kilometer $(\mathrm{km})$ of road is accessed by 33 motorized vehicles. The length of roads in Papua is $21,560 \mathrm{~km}$ while the number of vehicles is 721 .

Related to this, the implementation of a progressive tax rate on motorized vehicles in Papua Province as outlined in Regional legislation Number 4 of 2011 concerning Regional Taxes is irrelevant due to the objectives of implementing progressive tax in areas with a very dense population. The formulation of 
Regional legislation ignores the sociological aspects as requirements for legislation. The preparation of legal substance cannot deny the facts in the field otherwise it will result in functioning of the law ineffectively. The poor legal substance can affect the work of the legal structure.

Related to the description above, in the writer's opinion, the stages of community participation if implemented at the planning stage of drafting regional legislations concerning Regional Taxes in Papua Province will receive rejections from the community because they are considered not aspirational. The objective condition of vehicle ownership in Papua Province, especially four-wheeled vehicles, is more than one dilator behind the road transportation facilities that are inadequate so that the people themselves attempt to carry out private transportation.

Tax collections that burden the tax grid contradict the principle of the rule of law, considering that one element of it is the protection of human rights. Human rights are associated to individual independence from any pressure, at any time, and by anyone. Tax payments cannot contain elements of punishment, but tax payments by taxpayers set by the state must be made on the basis of willingness and awareness of taxpayers.

Regarding the issue of the interests of the people, it must be admitted that the roads provided by the government are very important to support all community activities, therefore the PKB payments relate to the burden of the road when used, namely: the burden of replacement for damage on the road due to road use expenses. Walters says that the economic of road user charge can be interpreted, that every highway user must pay a fee to the government because the vehicle causes damage to the highway (Walters, Alan Artur, 2012: 87).

In determining the PKB tariff, it is better to use the benefits received approach, as stated by Muchtaruddin Siregar, that road users or motorized vehicle owners are taxed in proportion to the benefits received. The tax is the same as the maintenance fee for every kilometer of road maintenance plus congestion fees (Muchtaruddin Siregar, 1981: 52). 
This approach has similarities to the use of toll road tariffs, meaning that road users are given the freedom to choose whether to use toll roads or regular roads. People who use the toll road are aware of the consequences of the costs that must be paid for the toll road service, but they can arrive at the destination faster than when they drive on normal roads.

The purpose of the rule of law is no other than to prosper the community (Welfare state). Regional legislations as legal products should be used as tools or means of social engineering; law must be used as a tool to alleviate community poverty (Suteki, 2013: 97).

\section{The Implementation of Motorized Vehicle Tax progressive tariffs in Papua Province in term of justice}

Satjipto Rahardjo states that talking about law means talking about human relations. In addition, talking about human relations means talking about justice (Satjipto Raharjdo, 2000: 159). Based on the above opinions, the formation of law is solely to achieve justice. Achieving justice will support the creation of a public order. Whereas welfare can only be achieved in an orderly society.

Justice, according to Noach Webster, is part of the abstract values that it has many meanings and connotations. In relation to the concept of justice, the word justice is defined as follows:

1. Quality to be righteous, honesty

2. Impartiality, fair on facts

3. Quality to be correct, right

4. Retribution as vindictive, reward, or punishment, rightfulness according to achievement or fault

5. Sound reason, rightfulness, validity

6. Use of power to maintain the right, just, or law (Noah Webster, 2012: 397).

In line with this, John Rawls argues that justice as fairness contains principles that independent and rational people who wish to develop their interests 
should obtain an equal position at the beginning and it is a fundamental condition for them to enter the association they want (Satjipto Rahardjo, 2000: 165).

Elucidation of Point or Letter g of Paragraph (1) Article 6 of Law Number 12 of 2011 concerning the Establishment of Legislation (UUPPP) explains that the principle of justice in the legislation is that each Material of Legislation must reflect justice proportional to every citizen. The purpose of proportional in this case is that each material containing law and regulation must avoid the possibilities that burden the community eliminating an imbalance at the time of the application of legislation. Law Number 28 of 2009 concerning regional taxes and Regional Retributions delegates the establishment of regional legislations concerning Regional Taxes in each region. Based on the law order, Regional legislation Number 4 of 2011 concerning Regional Taxes in Papua Province was formed.

How can the suitability in the use of the "Absolute Tax Liability Theory" in relation to the regional legislations in terms of the principle of the unitary state be relevant? In a unitary state, every citizen is bound by his or her rights and obligations. Rights and obligations must stand in a balanced manner. If it is associated with the obligation to pay taxes, it will lead to the taxpayer's right.

The PKB payment obligations as one type of local tax can support the provincial APBD. Paragraph (5) of Article 8 of Law Number 28 of 2009, stipulates that the revenue of the PKB shall be at least ten percent, including those distributed to District/City, allocated for the construction and or maintenance of roads and improvement of modes and means of public transportation.

Therefore, the improvement of regional income from the PKB sector will have implications for the improvement and provision of public facilities and infrastructure because it is one of the obligatory functions that become regional affairs (Public Works).

Below is a table on the length of roads in the Province of Papua based on the data from Papua Province Statistics Center in 2016. The total length of highway found in Papua Province is $2,957.78 \mathrm{~km}$.

Length of Road by Regency / City in Papua Province in 2016 


\begin{tabular}{|c|c|c|c|}
\hline No. & Regency/City & Length of Roads & Remarks \\
\hline 1 & Merauke & 419.10 & \\
\hline 2 & Jayawijaya & 150.60 & \\
\hline 3 & Jayapura & 384.20 & \\
\hline 4 & Nabire & 105.00 & \\
\hline 5 & Kepulauan Yapen & 175.05 & \\
\hline 6 & Biak Numfor & 172.00 & \\
\hline 7 & Paniai & 12.10 & \\
\hline 8 & Puncak jaya & 54.70 & \\
\hline 9 & Mimika & 162.10 & \\
\hline 10 & Boven Digoel & 141.00 & \\
\hline 11 & Mappi & 84.15 & \\
\hline 12 & Asmat & 10.50 & \\
\hline 13 & Yahukimo & 18.50 & \\
\hline 14 & Pegunungan Bintang & 44.00 & \\
\hline 15 & Tolikara & 60.40 & \\
\hline 16 & Sarmi & 37.70 & \\
\hline 17 & Keerom & 91.80 & \\
\hline 18 & Waropen & 102.50 & \\
\hline 19 & Supiori & 79.21 & \\
\hline 20 & Mamberamo raya & 75.60 & \\
\hline 21 & Nduga & 63.30 & \\
\hline 22 & Lani Jaya & 161.00 & \\
\hline 23 & Mamberamo Tengah & 34.10 & \\
\hline 24 & Yalimo & 98.00 & \\
\hline 25 & Puncak & 27.29 & \\
\hline 26 & Dogiyai & 8.00 & \\
\hline 27 & Intan Jaya & 9.00 & \\
\hline 28 & Daiyai & 72.50 & \\
\hline
\end{tabular}




\begin{tabular}{|c|r|r|l|}
\hline 29 & Kota Jayapura & 104.38 & \\
\hline \hline \multicolumn{2}{|c|}{ Total } & $\mathbf{2 , 9 5 7 . 7 8}$ & \\
\hline
\end{tabular}

Source: The Office of Public Works of Papua Province

Road Conditions by Regency / City in Papua Province in 2016

\begin{tabular}{|c|c|c|c|c|c|}
\hline No. & Regency/City & Good & $\begin{array}{l}\text { Fairly } \\
\text { Good }\end{array}$ & Damaged & $\begin{array}{l}\text { Severely } \\
\text { Damaged }\end{array}$ \\
\hline 1. & Merauke & 224.10 & 65.00 & 40.00 & 90.00 \\
\hline 2. & Jayawijaya & 83.50 & 10.00 & 9.80 & 47.30 \\
\hline 3. & Jayapura & 225.80 & 44.10 & 22.90 & 91.22 \\
\hline 4. & Nabire & 34.00 & 10.00 & 18.00 & 43.00 \\
\hline 5. & Kepulauan Yapen & 48.40 & 35.00 & 55.00 & 36.70 \\
\hline 6. & Biak Numfor & 92.00 & 12.00 & 68.00 & - \\
\hline 7. & Paniai & - & 12.10 & - & - \\
\hline 8. & Puncak jaya & - & 12.50 & - & 42.20 \\
\hline 9. & Mimika & 37.00 & 40.00 & 60.10 & 25.00 \\
\hline 10 . & Boven Digoel & 34.00 & - & 12.00 & 95.00 \\
\hline 11. & Mappi & 36.00 & - & - & 48.20 \\
\hline 12. & Asmat & 3.00 & - & - & 7.50 \\
\hline 13. & Yahukimo & 18.50 & - & - & - \\
\hline 14. & $\begin{array}{l}\text { Pegunungan } \\
\text { Bintang }\end{array}$ & 12.00 & - & 6.00 & 26.00 \\
\hline 15. & Tolikara & - & 29.90 & - & 39.50 \\
\hline 16. & Sarmi & - & - & 37.70 & - \\
\hline 17. & Keerom & - & 12.00 & 79.80 & - \\
\hline 18. & Waropen & 32.00 & - & 50.00 & 20.50 \\
\hline 19. & Supiori & 25.00 & - & 54.20 & - \\
\hline 20. & Mamberamo raya & - & - & 75.60 & - \\
\hline 21. & Nduga & - & - & - & 63.30 \\
\hline
\end{tabular}




\begin{tabular}{|c|l|c|c|c|c|}
\hline 22. & Lani Jaya & 6.00 & 26.50 & - & 128.50 \\
\hline 23. & $\begin{array}{l}\text { Mamberamo } \\
\text { Tengah }\end{array}$ & 17.00 & - & 17.10 & - \\
\hline 24. & Yalimo & - & 14.00 & - & 84.00 \\
\hline 25. & Puncak & - & 7.00 & - & 20.30 \\
\hline 26. & Dogiyai & - & 8.00 & - & - \\
\hline 27. & Intan Jaya & - & -9.00 & - & - \\
\hline 28. & Daiyai & - & 30.50 & - & 42.00 \\
\hline 29. & Kota Jayapura & 86.48 & 10.00 & - & 3.00 \\
\hline & Total & $\mathbf{1 , 0 1 4 .}$ & $\mathbf{3 7 8 . 6 0}$ & $\mathbf{6 1 . 2 0}$ & $\mathbf{9 5 3 . 2 2}$ \\
\hline
\end{tabular}

The Office of Public Works of Papua Province in 2016 recorded 2,597.78 $\mathrm{km}$ of roads in Papua Province as provincial roads. Some of these roads $(1,932.46 \mathrm{~km})$ have not been asphalted while the rest $(1,025.18 \mathrm{~km})$ are asphalted. Based on their conditions, $1,014.78 \mathrm{~km}$ of the roads are good but $953.22 \mathrm{~km}$ are severely damaged.

The total number of motorized vehicles in Papua Province is 632,991. While motorbikes as vehicles that dominate in Papua Province are 524,144 units.

Number of Motorized Vehicles in Papua Province in 2017

\begin{tabular}{|r|l|r|r|r|r|}
\hline No. & Regency/City & \multicolumn{1}{c|}{ Cars } & \multicolumn{1}{c|}{ Buses } & \multicolumn{1}{c|}{ Trucks } & Motorbikes \\
\hline \hline 1. & Merauke & 4,345 & 14 & 4,698 & 81,024 \\
\hline 2. & Jayawijaya & 1,147 & 1,115 & 6,307 & 20,461 \\
\hline 3. & Jayapura & 14,846 & 210 & 8,314 & 84,441 \\
\hline 4. & Nabire & 4,969 & 57 & 3,469 & 60,025 \\
\hline 5. & Kepulauan & & 25 & 884 & 15,426 \\
\hline 6. & Yapen & 940 & 19 & 1,534 & 35,830 \\
\hline 7. & Paniai & 4,770 & 2 & 26 & 1,033 \\
\hline 8. & Puncak jaya & 152 & - & 115 & 1,345 \\
\hline 9. & Mimika & 3,601 & 1,066 & 1,845 & 33,694 \\
\hline 10. & Boven Digoel & 774 & 26 & 878 & 6,193 \\
\hline
\end{tabular}




\begin{tabular}{|c|c|c|c|c|c|}
\hline 11. & Mappi & 271 & 2 & 76 & 2,149 \\
\hline 12. & Asmat & - & - & - & - \\
\hline 13. & Yahukimo & 11 & 14 & 96 & 1,985 \\
\hline 14. & $\begin{array}{l}\text { Pegunungan } \\
\text { Bintang }\end{array}$ & - & - & - & - \\
\hline 15 . & Tolikara & - & - & - & - \\
\hline 16. & Sarmi & 237 & 43 & 483 & 5,239 \\
\hline 17. & Keerom & 1,884 & 33 & 1,080 & 12,561 \\
\hline 18. & Waropen & 663 & 33 & 469 & 1,321 \\
\hline 19. & Supiori & 144 & 45 & 104 & 1.121 \\
\hline 20. & $\begin{array}{l}\text { Mamberamo } \\
\text { raya }\end{array}$ & - & - & - & - \\
\hline 21. & Nduga & - & - & - & - \\
\hline 22. & Lani Jaya & - & - & - & - \\
\hline 23. & $\begin{array}{l}\text { Mamberamo } \\
\text { Tengah }\end{array}$ & - & - & - & - \\
\hline 24. & Yalimo & - & - & - & - \\
\hline 25. & Puncak & - & - & - & - \\
\hline 26. & Dogiyai & - & - & - & - \\
\hline 27. & Intan Jaya & - & - & - & - \\
\hline 28. & Daiyai & - & - & - & - \\
\hline 29. & Kota Jayapura & 26,264 & 862 & 10,453 & 160,296 \\
\hline & Total & 64,460 & 3,566 & 40,821 & 524,144 \\
\hline
\end{tabular}

Source: Papua Province Statistics Center in 2017

The level of vehicle density is one of the objectives of a progressive tax arrangement, and it can be obtained by dividing the length of the roads by the number of vehicles. The calculations are as follows:

2,597.78: $632.991=0.0041$, meaning that if the total number of vehicles in Papua Province are simultaneously used on the highway, the number of four- 
wheeled vehicles is $0.0041 \mathrm{units} / \mathrm{km}$. This number is so small that the rationale for imposing progressive tariffs in Papua Province is not urgent.

Based on considerations made by the formulator of the tax law, the policy of a progressive tax rate on motorized vehicles is aimed at reducing the growth rate of motorized vehicles that are accelerating by an average of around $14 \%$ per year while the average road growth is around $4 \%$ per year. Progressive taxes, applied by regional authority to ownership of second vehicles and so on, are aimed at reducing congestion in urban areas (Bustamar Ayza, 2017:104).

\section{E. CLOSING}

\section{Conclusion}

a. The formulation of Regional legislation Number 4 of 2011 concerning Regional Taxes in Papua Province has not fully reflected the efforts to establish good legislation because it ignores the methods and standards mandated by the PPP Law, especially in the considering section. Thus this regional legislation deviates from its real goal that is meeting the people's needs for legislation.

b. Regional legislation Number 4 of 2011 concerning regional taxes in Papua Province contradicts the principle of justice. It requires taxpayers to pay the $\mathrm{PKB}$, as progressive tariffs, for the second ownership of fourwheel vehicles and so on while the regional government has not prepared an adequate alternative facility as a means of public transportation for the people.

\section{Sugestion}

a. The content of the Regional legislation Number 4 of 2011 concerning regional taxes in Papua Province should accommodate the objective conditions of Papua Province region so that the community's compliance with the enactment of the regional legislation can be effectively aligned with the objectives of establishing the Regional legislation. 
b. In order to comply with the laws and regulations in Papua Province, especially regarding Regional Taxes, it is necessary to conduct a judicial review of the regional legislations because they contradict the principles of justice as intended by law.

\section{BIBLIOGRAPHY:}

\section{Books:}

Ayza, Bustamar, 2017, Hukum Pajak Indonesia, Kencana: Depok.

Ibrahim, Johny, 2006, Teori dan Metodologi Penelitian Hukum Normatif, Bayumedia Publising: Malang.

Raharjdo, Satjipto, 2000, Ilmu Hukum, Citra Aditya Bakti: Bandung.

Samudra, Azhari Aziz, Perpajakan di Indonesia Keuangan, Pajak dan Retribusi Daerah, Raja Grafindo Persada: Jakarta

Siregar, Muchtaruddin, 2012, Beberapa Masalah Ekonomi dan Manajemen Penganggkutan, Jakarta: LPFE-UI,1981 Noah Webster, in H.M. Erfan Helmi Juni, Filsafat Hukum, Pustaka Setia: Bandung,.

Soemitro, Ronny Hanitijo, 1988, Metodologi Penelitian Hukum dan Jurimetri, Ghalia Indonesia: Jakarta.

Suteki, 2013, Desain Hukum Di Ruang Sosial, Thafa Media: Semarang.

Yani, Ahmad, 2013, Pembentukan Peraturan Perundang-undangan yang Responsif (Catatan atas UU No. 12 Tahun 2012 tentang Pembentukan Peraturan perundang-undangan), Konstitusi Press (Konpress): Jakarta 